\title{
THE MEDIATING ROLE OF DEBT AND DIVIDEND POLICY ON THE EFFECT PROFITABILITY TOWARD STOCK PRICE
}

\author{
Akhmadi Akhmadi', Nurohman Nurohman ${ }^{2}$, Robiyanto Robiyanto ${ }^{3 *}$ \\ ${ }^{1,2}$ Universitas Sultan Ageng Tirtayasa, Jl. Pakupatan, Panancangan, Kec. Cipocok Jaya, Kota Serang, Banten 42124 \\ ${ }^{3}$ Universitas Kristen Satya Wacana, Jl. Diponegoro No.52-60, Salatiga, Jawa Tengah 50711 \\ e-mail: ${ }^{1}$ akhmadi@untirta.ac.id, ${ }^{2}$ nurohmanuntirta@gmail.com, ${ }^{3 *}$ robiyanto@staff.uksw.edu \\ *Corresponding author
}

\begin{abstract}
This study aimed to obtain an empirical explanation of the role of debt policy and dividend policy as variables mediating the influence of profitability on stock prices. This study used six mining companies listed on the Indonesia Stock Exchange (IDX) during the period of 2012-2016 as samples, hence there were 30 observational data. The sampling technique in this study was purposive sampling. This study found that profitability had a positive effect on stock prices, but the increasing profitability would not necessarily reduce the debt policy. The increasing profitability did not significantly increase the dividend policy, however, increasing dividend policy would increase the stock prices. The results also proved that debt and dividend policy did not mediate the influence of return on equity on the stock prices.
\end{abstract}

Keywords: Return on equity; debt to equity ratio; dividend payout ratio; stock price.

\section{Introduction}

The mining industry is one of the pillars of economic development in a country, including Indonesia which has a lot of potential for natural resources. Its role as a provider of minerals/energy resources is highly necessary for the country's economic growth because companies in the mining industry have different characteristics compared to other industries. Huge, long-term, risky and highly uncertain investment costs make funding as a major issue in relation to the mining company development. The mining sector also facing some specific regulations which make this sector as one of the highly regulated sectors. This fact is reflected in fluctuations in the stock prices of the mining companies.

The fluctuations or movements in the stock prices can occur due to many factors, such as commodity prices. Arfaoui and Ben Rejeb (2017) found that the world oil price movement has a significant effect on the stock price, this finding also supported by Hersugondo, Robiyanto, Wahyudi, and Muharam (2015); Robiyanto (2018), while Putra and Robiyanto (2019) found that the precious metal prices can affect the mining stock price. This could happen because these commodities prices can affect the profitability level. Hunjra, Shahzad, Chani, Hassan, and Mustafa (2014); Martins and Lopes (2016); Muryanti and Subowo (2017); Subiyantoro and Andreani (2013) found that the company's stock price would increase along with the increase in the company's profitability. It is in contrast to Indrawati and Suprihhadi (2016); Lewellen, Loderer, and Martin (1987) who proved that the influence of profitability on the stock prices was negative. Several previous studies also provide clues that debt policy was such a factor influencing the relationship between the two variables. Desmintari and Yetty (2016), Hermuningsih (2013), Murtiningtyas (2012), Onofrei, Tudose, Durdureanu, and Anton (2015) highlighted that profitability had a significant influence on debt policy with a negative relationship. Researches by Bahreini, Baghbani, and Bahreini (2012); Margaretha and Rizki (2010) explained that a high debt ratio would lower the stock prices. While Margaretha and Rizki (2010) who used samples from the manufacturing sector listed on the IDX found different results. They found that profitability has a positive effect on the debt policy in the manufacturing sector in the IDX. Eviani (2015) also found a similar result by using samples from various industries listed on the IDX.

The results of previous studies also provided clues that the dividend policy was a factor that influenced the relationship between profitability and stock prices. Khan and Meer (2017) revealed that profitability had a significant positive effect on dividend policy. Nurlita and Robiyanto (2018); Zakaria, Muhammad, and Zulkifli (2012) also confirmed that the greater the dividend payout ratio policy, the higher the stock prices. However, Adaoglu (2000) stated that investors in emerging markets tend to less concerned with volatility in dividends over time, this statement supports the dividend irrelevant theory developed by Miller and Modigliani (1961).

The difference in the previous research results shows that there is a gap between profitability and 
stock prices. It is believed that it happens because there are other variables influencing the relationship between profitability and stock prices. Therefore, for these reasons, it is necessary to review the relationship between the profitability and stock prices by including the debt policy and dividend policy as intervening variables in the research model. This follows Bessler and Nohel (2000) research. Both variables are believed to be able to strengthen the relationship between profitability and stock prices in the mining companies listed on the IDX during the period of 2012-2016.

The contribution of this study is, although research on the relationship between profitability and stock prices involving debt policy and dividend policy had been done previously, its nature is still partial where they only involved the debt policy or dividend policy partially in their research model. In this study, both debt policy and dividend policy are both used as mediating variables in the relationship between profitability and stock prices.

The remainder of this paper is organized as follows. Section 2 discusses hypotheses development. Section 3 presents the data and method. Section 4 presents the result and discussion. Finally, the last section concludes and recommends some implications.

\section{Hypotheses Development}

Signaling theory emphasizes the importance of information released by companies on investment decisions of parties outside the company. Information is an important element for investors and business people because the information essentially presents information, notes or pictures both for the past, current and future conditions for the survival of a company. Complete, relevant, accurate and timely information is needed by investors in the capital market as an analytical tool for making investment decisions. Some information that can give signals is profitability, debt policy and dividend policy.

Debt policy is often represented by a capital structure. Capital structure is a ratio that shows the ratio between debt and equity and important issues in spending decisions. The capital structure can affect the value of the company because a lot of capital sourced from investors or creditors does not necessarily reflect good company performance. Companies that have the capital to run production activities and are ready to sell their products will expect profits from each of their activities. Whereas dividend policy is usually represented by a dividend payout ratio that shows the percentage of net income distributed as dividends. In every activity the company will maximize profits, this is done so that every stakeholder is not disappointed with the company's performance. There are many factors to consider in assessing company performance. This underlies research on factors that are able to have an impact on stock prices as a proxy for company value.

Growth of profitability is a factor used in assessing the company's future prospects (Handriani \& Robiyanto, 2018a, 2018b). The higher the profitability, the more the profits generated by the company. This indicates that the company can provide greater returns to the shareholders and meet all investment needs. This is consistent with the signaling theory which states that good profitability growth is a signal that the company is operating well. Companies that manage their sources of funds properly will provide positive input for the investors so that they are able to attract more investors to buy stocks and invest their funds in the company. This makes the demand for stocks increase and the price will be higher (Acheampong, Agalega, \& Shibu, 2014).

Previous empirical studies found that high profitability positively influenced stock prices. Nurlita and Robiyanto (2018) analyzed the comparison of the influence of liquidity, solvency, and profitability on stock prices in sharia stocks. With multiple linear regression analysis techniques, the results showed that there was a positive effect of profitability on stock prices. A study by Hunjra et al. (2014) studied 63 companies in the Karachi capital market in the period of 2006-2011. The data was analyzed using OLS regression models with panel data. It was found that profitability (ROA and EPS) had a significant positive impact on stock prices. Other previous research results also confirm that there was a positive influence of profitability on stock prices (Indrawati \& Suprihhadi, 2016). For this reason, hypothesis 1 is formulated as follows

$H_{I}$ : An increasing profitability will result in an increase in stock prices.

Profitability reflects earnings for investment funding. The relationship of profitability to debt policy is established by the pecking order theory which explains that companies with a high profit actually have a low debt level. According to Hang, Geyer-Klingeberg, Rathgeber, and Stöckl (2018), managers applied the pecking order theory for funding decisions. The company does not need external funding because a high level of profit makes enough internal funds to meet investment needs. Previous empirical studies prove that profitability had a negative effect on debt policy, meaning that with the ability to obtain high 
profitability, the decision to use debt as a source of funding was low. Murtiningtyas (2012) analyzed the effect of dividend policy, managerial ownership, institutional ownership, profitability, business risk on the debt policy of 40 manufacturing companies listed on the Indonesia Stock Exchange in the period of 2008-2010. The finding shows that profitability had a significant effect on debt policy with a negative relationship.

Desmintari and Yetty (2016) conducted a study and had a sample of 12 trading companies listed on the Indonesia Stock Exchange in the period of 2011-2014. The results showed that profitability had a significant influence on the debt policy with a negative relationship. An increase in the level of profitability would allow companies to reduce their desire to use debt policies. Several previous studies also prove the negative influence of profitability on debt policy (Haron, Ibrahim, Nor, \& Ibrahim, 2013; Murhadi, 2011; Nnadi, 2016; Onofrei et al., 2015; Sahabuddin, 2017). For this reason, hypothesis 2 is formulated as follows

$H_{2}$ : An increasing profitability will result in a decrease in debt policy.

Based on the signaling theory, the shareholders rely on dividend payments as a signal of company performance. The profit generated by the company is a positive signal for them to obtain the expected dividends. The greater the profits, the more the dividend received by the shareholders (Ernayani, Oktiviana, \& Robiyanto, 2017). Previous empirical studies state that profitability had a positive effect on dividend policy (Al-Malkawi, Rafferty, \& Pillai, 2010; Gill, Biger, \& Tibrewala, 2010; Zakaria et al., 2012). For this reason, hypothesis 3 is formulated as follows:

$H_{3}$ : An increasing profitability will result in an increase in dividend policy.

Based on the signaling theory, the debt policy ratio is used to determine how much equity the shareholders have in covering the company's overall debt, so that an appropriate return can still be obtained (Hang et $a l ., 2018)$. The greater the ratio, the less profitable the company is considered due to the large debt risk burden borne by failures that may occur in the company which can reduce the company value and ultimately reduces the stock prices. Previous empirical studies have found that debt policy had a negative effect on stock prices (i.e. Bahreini et al., 2012). Bahreini et al. (2012) analyzed financial leverage with stock prices and the company's operational performance on the Tehran stock market. The study was conducted on 145 companies in Tehran's Stock Market during the period of 2005-2006 using multiple regression analysis techniques. The results showed that there was a negative significant relationship between economic leverage and stock prices. For this reason, hypothesis 4 is formulated as follows:

$H_{4}$ : An increasing debt policy will result in a decrease in stock prices.

In the signaling theory, the existence of dividend changes can give signals to external parties about the company's prospects in the future. An increase in dividend payments is considered a good signal because it illustrates the conditions and good prospects of the company so that it can affect the stock price increase (Hang et al., 2018). Several empirical studies state that dividend policy had a positive effect on stock prices i.e. Hunjra et al. (2014) and Ernayani et al. (2017). They confirmed that there was a positive influence of dividend policy on stock prices. For this reason, hypothesis 5 is formulated as follows:

$H_{5}$ : An increasing dividend policy will result in an increase in stock prices.

\section{Research Method}

The population of this study is 41 mining companies listed on the Indonesia Stock Exchange (IDX). However, only 6 companies met the criteria based on purposive sampling. Details are shown in Table 1. The companies selected as research samples are Adaro Energy Open, Tbk (ADRO); Indo Tambangraya Megah, Tbk (ITMG); Resource Alam Indonesia, Tbk (KKGI); Bukit Asam Coal Mine, Tbk (PTBA); Elnusa, Tbk (ELSA); and Radiant Utama Interinsco, Tbk (RUIS). These samples can represent all the members of the population because it consists of various sub-sector (i.e. coal, metal, oil, and minerals), also these samples been listed in the IDX for more than ten years.

The data was collected using documentation techniques by collecting relevant data from various sources both from ICMD (Indonesian Capital Market Directory) and the official website of the Indonesia Stock Exchange (www.idx.co.id) about the annual financial statements of mining companies during the period of 2012-2016. Meanwhile, to collect more information related to previous theories, concepts, and journals, library techniques were used.

This study consists of four variables including (1) Profitability (proxied by Return On Assets (ROA)) which refers to the ratio between earnings after tax and total assets; (2) Debt Policy (proxied by Debt to Equity 
Ratio (DER)) which refers to the ratio between total debt and total own capital; (3) Dividend Policy (proxied by Dividend Payout Ratio (DPR)) which refers to the ratio between dividends per share and net income per share; and (4) Stock Prices (proxied by Yearly Closing Price) which refer to the company's stock price at the end of the year during the research period as used by Murniati (2016); Subiyantoro and Andreani (2013); Wijaya (2017).

Table 1

\section{Sample Selection Criteria}

\begin{tabular}{lc}
\hline \multicolumn{1}{c}{ Criteria } & Total \\
\hline $\begin{array}{l}\text { Mining companies listed on the IDX during } \\
\text { the period of 2012-2016 }\end{array}$ & 41 \\
$\begin{array}{l}\text { It provides complete information related to } \\
\text { the data needed during the study period }\end{array}$ & 39 \\
$\begin{array}{l}\text { Makes dividend payments during the study } \\
\text { period }\end{array}$ & 6 \\
Total sample & 6 \\
\hline
\end{tabular}

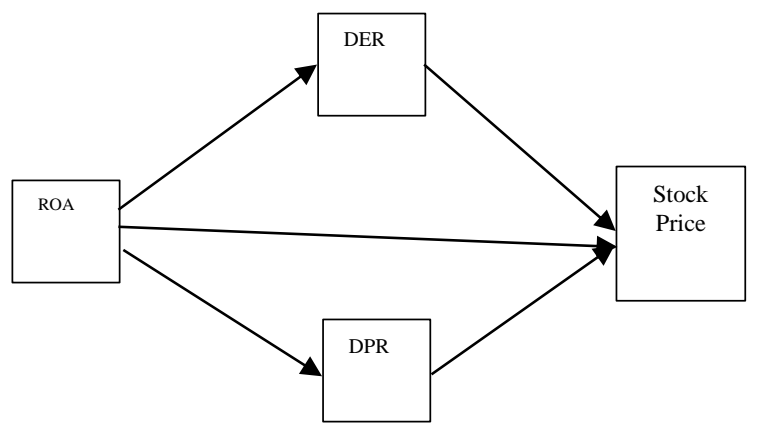

Figure 1. Research model

This study used descriptive statistical analysis and inferential statistics consisting of: (1) classical assumption tests (including normality, multicollinearity, heteroscedasticity, and autocorrelation test); (2) partial hypothesis test; and (3) mediation test. The mediation test consisted of causal steps developed by Baron and Kenny (1986). The variable $\mathrm{M}$ is considered mediating if equation 1,2 and 3 meet the respective criteria of $Y$ $(c \neq 0) ; M(\mathrm{a} \neq 0) ; Y(b \neq 0)$.

\section{Result and Discussion}

\section{Result}

\section{Descriptive Statistics}

Descriptive statistics analysis aims to describe the distribution of ROA, DER, DPR and SP data from 30 observational data obtained. It used frequency parameters that present minimum, maximum, mean (mean) and standard deviation values, the results of which are presented in Table 2.
Table 2

Descriptive Statistics

\begin{tabular}{lcrrrr}
\hline & $N$ & \multicolumn{1}{c}{ Min. } & \multicolumn{1}{c}{ Max. } & \multicolumn{1}{c}{ Mean } & \multicolumn{1}{c}{ Std. Dev. } \\
\hline ROA & 30 & 2.53 & 28.90 & 10.65 & 6.09 \\
DER & 30 & .17 & 4.41 & 1.06 & 1.07 \\
DPR & 30 & .17 & 210.99 & 42.97 & 38.99 \\
Stock & 30 & 84 & 41550 & 5106.0 & 9604.75 \\
Price & & & & 0 & \\
\hline
\end{tabular}

Based on the results in Table 2, the ROA ratio has an average value of 10.65 which means that the average mining company was able to generate a net profit of $10.65 \%$ of the total assets owned. The minimum value of ROA is 2.53 and a maximum of 28.9 shows that the lowest sample company was only able to generate a net profit of $2.53 \%$ of total assets and the highest was able to generate a net profit of $28.9 \%$ of total assets. The standard deviation value of 6.09 shows that the ROA ratio owned by mining companies in 2012-2016 was quite varied.

The DER value has an average of 1.06 , which means the average debt owed by mining companies was 1.06 times the capital owned. These results indicate that in 2012-2016, the sample companies on average had a fairly low debt. A minimum value of 0.17 , a maximum of 4.41 and a standard deviation of 1.07 shows the ability of mining companies to use debt varied greatly. During the study period, there were companies that used debt only 0.17 times of their capital while other companies used debt up to 4.41 times of their capital.

The average dividend policy ratio is 42.97 , which means that the average mining company paid a dividend of $42.97 \%$ of the net profit per share outstanding. These results indicate that the sample companies, in general, had a fairly high dividend payout ratio. The minimum value of 0.17 and a maximum of 210.99 shows that in 2012-2016, there were companies that paid very low dividends of only $0.17 \%$ of the net profit of their stocks and some others made very high dividend payments which reach $210.99 \%$. The standard deviation of 38.99 shows that the ratio of dividend payments from sample companies was quite diverse.

The average stock price was IDR 5,106 at the closing price as of December 31 of the research year. These results indicate that in 2012-2016, the closing stock price of mining companies was quite high. The minimum Stock Price value is 84 and a maximum of 41,550 shows that the lowest sample company succeeded in closing the sale of the share price of IDR 84 and the highest of IDR 41,550 at the end of December of the observation year. The standard deviation of 9,604.75 shows that the selling price of the closing stocks of mining companies in 2012-2016 varied greatly. 


\section{Classical Assumption Test}

Normality Test.

The normality test of this study used the OneSample Kolmogorov-Smirnov Test for the residual as suggested by Ghozali (2011). The result shows that the test statistic is 0.08 with probability value 0.20 which indicates that the residual is normally distributed. This method also used by various studies i.e. Chabachib, Windriya, Robiyanto, and Hersugondo (2019); Nurlita and Robiyanto (2018).

\section{Multicollinearity Test.}

The results of the multicollinearity test are presented in Table 3.

\section{Table 3}

\section{Multicollinearity Test Results}

\begin{tabular}{ll}
\hline & VIF \\
\hline ROA & 1.07 \\
DER & 1.19 \\
DPR & 1.23 \\
\hline
\end{tabular}

Table 3 shows that the ROA, DER, and DPR have the VIF values of $1.07,1.19$, and 1.23 which is less than 10 , then there is no multicollinearity problem found.

\section{Autocorrelation Test.}

Autocorrelation test conducted using the DurbinWatson (DW) statistic. The result shows that the DW statistics are 2.01 which laid between 1.5-2.5. So it concluded that no autocorrelation problem occurs.

\section{Heteroscedasticity Test.}

The heteroscedasticity test using the Glejser test was done to see whether there is heteroscedasticity or not. The results are presented in Table 4. None independent variable has a significant effect on the absolute residual value. For this reason, there is no heteroskedasticity in the regression model.

Table 4

Glejser Test Results

\begin{tabular}{ccc}
\hline & $t$-statistics & Probability Value \\
\hline ROA & -1.10 & 0.28 \\
DER & -1.09 & 0.29 \\
DPR & -0.31 & 0.75 \\
\hline
\end{tabular}

\section{Hypotheses Testing}

The test on the influence of profitability on stock prices shows $t$-value $=4.43>t$-table $=1.70$ with $p$ - value of $0.00<$ alpha $(\alpha)=0.05$. Thus, hypothesis $1-$ stating that increasing profitability will result in an increase in stock prices - is supported. Then, the test on the influence of profitability on debt policy shows $t$ value $=0.51<t$-table $=1.70$ and $p$-value of $0.61>$ alpha $(\alpha)=0.05$. Thus, hypothesis $2-$ stating that increasing profitability will result in a decrease in debt policy - is not supported. Further, the test on the influence of profitability test on dividend policy shows $t$-value $=1.03\langle t$-table $=1.70$ with $p$-value of 0.31$\rangle$ alpha $(\alpha)=0.05$. Thus, hypothesis 3 - stating that increasing profitability will result in an increase in the dividend policy - is not supported. In addition, the test on the influence of debt policy on stock prices shows $t$ value $=-3.07<t$-table $=-1.70$ with $p$-value of $0.00<$ alpha $(\alpha)=0.05$.

These results indicate that hypothesis 4 - stating that an increasing debt policy will result in a decrease in stock prices - is accepted. Finally, the test on the influence of dividend policy on stock prices shows $t$ value $=2.97>t$-table $=1.70$ with $p$-value of $0.00<$ alpha $(\alpha)=0.05$. The results indicate that the hypothesis 5 - stating that an increasing dividend policy will result in an increase in stock prices - is supported.

\section{Mediation Test}

The indirect test of the influence of profitability (through debt policy and dividend policy) on stock prices used the causal step parameter developed by Baron and Kenny (1986). The debt to equity ratio mediation test uses the following 3 equations:

$$
\begin{aligned}
& \mathrm{SP}=\alpha+\beta_{1} \mathrm{ROA}+\varepsilon_{1} \\
& \mathrm{DER}=\alpha+\beta_{1} \mathrm{ROA}+\varepsilon_{1} \\
& \mathrm{SP}=\alpha+\beta_{1} \mathrm{ROA}+\beta_{2} \mathrm{DER}+\beta_{3} \mathrm{DPR}+\varepsilon_{3}
\end{aligned}
$$

Whereas the dividend payout ratio test uses the following 3 equations. Equation (1) and equation (3) similar to previous equations.

$$
\begin{aligned}
& \mathrm{SP}=\alpha+\beta_{1} \mathrm{ROA}+\varepsilon_{1} \\
& \mathrm{DPR}=\alpha+\beta_{1} \mathrm{ROA}+\varepsilon_{2} \\
& \mathrm{SP}=\alpha+\beta_{1} \mathrm{ROA}+\beta_{2} \mathrm{DER}+\beta_{3} \mathrm{DPR}+\varepsilon_{3}
\end{aligned}
$$

Equation 1 presents the coefficient of return on assets of 0.54 and $t$-value $=3.45>t$-table $=1.70$ with $p$-value of $0.00<$ alpha $(\alpha)=0.05$. This result shows a significant positive value. Equation 2 presents the coefficient of return on assets of 0.033 and the $t$-value $=0.51<t$-table $=1.70$ with $p$-value $0.61>$ alph $(\alpha)$ $=0.05$. This result shows an insignificant positive value. 
Table 5

\section{Result of Equation 1}

\begin{tabular}{cccc}
\hline & $\begin{array}{c}\text { Unstandardized } \\
\text { Coefficient }\end{array}$ & $\begin{array}{c}\text { Standardized } \\
\text { Coefficient }\end{array}$ & $t$-value \\
\hline Constant & 5.38 & & $9.68^{*}$ \\
ROA & 0.15 & 0.54 & $3.45^{*}$ \\
\hline
\end{tabular}

Notes:

* significant at $\alpha=1 \%$

The dependent variable is Stock Price

Table 6

Result of Equation 2

\begin{tabular}{cccc}
\hline & $\begin{array}{c}\text { Unstandardized } \\
\text { Coefficient }\end{array}$ & $\begin{array}{c}\text { Standardized } \\
\text { Coefficient }\end{array}$ & t-value \\
\hline Constant & 0.87 & & $2.16^{*}$ \\
ROA & 0.01 & 0.09 & 0.51 \\
\hline
\end{tabular}

Notes:

* significant at $\alpha=5 \%$

The dependent variable is DER

Table 7

Result of Equation 3

\begin{tabular}{cccc}
\hline & $\begin{array}{c}\text { Unstandardized } \\
\text { Coefficient }\end{array}$ & $\begin{array}{c}\text { Standardized } \\
\text { Coefficient }\end{array}$ & $t$-value \\
\hline Constant & 5.42 & & $11.18^{*}$ \\
ROA & 0.14 & 0.51 & $4.43^{*}$ \\
DER & -0.61 & -0.37 & $-3.07^{*}$ \\
DPR & 0.01 & 0.36 & $2.97^{*}$ \\
\hline
\end{tabular}

Notes:

* significant at $\alpha=1 \%$

The dependent variable is Stock Price

Equation 3 presents the coefficient of return on assets of 0.51 and the $t$-value $=4.43<t$-table $=1.70$ with $p$-value $0.00<$ alpha $(\alpha)=0.05$. This result shows a significant positive value.

Table 8

Result of Equation 4

\begin{tabular}{cccc}
\hline & $\begin{array}{c}\text { Unstandardized } \\
\text { Coefficient }\end{array}$ & $\begin{array}{c}\text { Standardized } \\
\text { Coefficient }\end{array}$ & $t$-value \\
\hline Constant & 29.94 & & $2.06^{*}$ \\
ROA & 1.22 & 0.19 & 1.03 \\
\hline
\end{tabular}

Notes:

$*$ significant at $\alpha=5 \%$

The dependent variable is DPR

Noting on these results, only Equation 1 and 3 which present significant results while Equation 2 does not. Baron and Kenny (1986) explained that the variable $M$ was expressed as a mediating or intervening variable between variable $X$ against variable $Y$ if Equation 1,2 and 3 met the criteria of $Y(c \neq 0), M(a \neq$ $0)$, and $Y(b \neq 0)$. Each of these criteria shows a significant effect. Therefore, it can be concluded that the debt policy proxied by the debt to equity ratio could not be considered as a mediating variable. In other words, the debt to equity ratio did not mediate the influence of return on equity on the stock prices.

Equation 4 presents the coefficient of return on assets of 1.22 and $t$-value of $1.03<t$-table $=1.70$ with $p$-value $0.31>$ alpha $(\alpha)=0.05$. This result shows an insignificant positive value.

Based on these results, only Equation 1 and 3 which present significant results while Equation 4 does not. The variable $M$ was expressed as a mediating or intervening variable between variable $X$ against variable $Y$ if Equation 1, 2 and 4 met the criteria of $Y$ (c $\neq 0), M(a \neq 0)$, and $Y(b \neq 0)$. Each of these criteria shows a significant effect. Therefore, it can be concluded that the dividend policy proxied by the dividend payout ratio could not be considered as a mediating variable. In other words, the dividend payout ratio did not mediate the influence of return on equity on the stock prices.

\section{Discussion}

\section{The Influence of Probability on Stock Prices}

The test result of the influence of profitability on stock prices is as predicted by the researchers earlier where increasing profitability would result in an increase in stock prices. The results are in accordance with Acheampong et al. (2014); Hunjra et al. (2014); Nurlita and Robiyanto (2018) who mentioned that profitability was a factor used in assessing the company's future prospects and shareholder returns. The results are consistent with the signaling theory, emphasizing that good profitability growth was a signal that the company was operating well so that it could attract more investors to buy stocks.

The results imply that the higher the company's ability to generate profits, the more the investors trust the performance of management and the industry's prospects. This increased confidence in the investors' optimism to survive and even increased the investment in this sector or industry. Simultaneously, this optimism would encourage other investors who were not in the industry to join and make transactions with the stocks. This would lead to stock prices to continue to rise.

\section{The Influence of Probability on Debt Policy}

The test results do not match the expectations of the researchers earlier (Haron et al., 2013; Nnadi, 2016; Onofrei et al., 2015; Sahabuddin, 2017). The results provide evidence that increasing profitability 
did not necessarily reduce debt policy. The results are not in accordance with the pecking order theory where the companies with high profitability ability used lower external funding (debt) because the internal funds were sufficient to sustain investment (Handriani \& Robiyanto, 2018a).

The results are also not relevant to empirical studies conducted by Desmintari and Yetty (2016). The results imply that there was a tendency for policymaking related to corporate debt which did not consider the level of profitability of the company. It seemed that the management continued to adopt a policy of increasing debt only when needed, although there was an increase in the company's profitability capability. This indicated that the contribution of internal funds from corporate profits was still relatively low in supporting corporate funding.

\section{The Influence of Profitability on Dividend Policy}

The test results on the influence of profitability on dividend policy are not in accordance with AlMalkawi et al. (2010); Gill et al. (2010); Zakaria et al. (2012). The results prove that increasing profitability would not significantly increase the dividend policy. It is in contrast with the signaling theory that explained that the profits obtained by the company were a positive signal for shareholders to obtain the expected dividends. The results imply that there was a policy trend to increase or decrease the dividend ratio which did not base on how much the company's ability to generate profits in the current year.

This was possible because the decision to increase or decrease the dividend ratio could also be based on the position of the retained earnings. It was probably that although the profit in the current year did not increase, the dividend ratio could be increased, and vice versa where there was an increase in the profitability in the current year, the dividend ratio did not increase due to the need for an increase in the retained earnings for certain purposes.

\section{The Influence of Debt Policy on Stock Prices}

The results proved that an increasing debt policy would reduce stock prices. The results are in accordance with the signaling theory where the greater the debt ratio, the greater the company risk and the possibility of failure. It would simultaneously reduce the investors' confidence, lowering stock prices. The results are relevant to the results of empirical studies by Bahreini et al. (2012). The results imply that there was a tendency of the investors' behavior not to respond positively to every management's decision to increase their debt ratios because they would increase the risk of funds invested in this industry.

Thus, whenever the management insisted on adopting a policy of increasing debt, the investors would immediately release their stocks to the market and simultaneously lowering the stock prices. This would have an impact on other or potential investors who wanted to join the industry. It discouraged them. As a result, the stock prices would be getting lower and lower.

\section{The Influence of Dividend Policy on Stock Prices}

The test result of the influence of dividend policy on stock prices is in line with Hunjra et al. (2014) and Ernayani et al. (2017). The results prove that an increasing dividend policy would increase stock prices. The results are in accordance with the signaling theory that changes in dividend policy might provide (good or bad) signals to the external parties on the company's future prospects. The results imply that there was a tendency for the investors to respond positively to each policy increasing dividend ratios because dividends were one of its investment objectives.

Increasing the dividend ratio was believed by investors as a good prospect for the company in the future. Thus, investors would increase their investment in this industry. This encouraged other investors (outside this industry) to join and buy stocks of the companies in this industry. In contrast, if the company adopted a policy of reducing the dividend ratio, the investors would respond negatively. They believed that the company did not provide a return in accordance with the investors' expectations. This response was usually followed by releasing stocks and simultaneously decreasing the stock prices.

\section{The Influence of Indirect Effect of Profitability (Through Debt Policy) on Stock Prices}

The results prove that the debt policy proxied by the debt to equity ratio did not mediate the influence of return on equity on stock prices. The results imply that the company's profitability ability did not have a significant impact on the debt policy decided by the company's management. This indicated that the level of profit generated by the company was not the basis for determining the company's debt policy. However, according to the pecking order theory, the level of profitability of a company was closely related to the ability of the company's internal funds. The higher the profitability, the stronger the internal funds through an increase in the retained earnings to reduce dependence on external funds (debt). 
Different things would certainly cause a higher dependence on funding from debt if the level of profitability of the company was lower. The debt policy adopted by the management also did not become the basis for investors to make decisions on their investments. However, according to the signaling theory, the greater the debt ratio, the less profitable the company. It was due to the large risk that must be borne for failures of funding decisions.

The results imply that there might be a tendency where the management did not really consider the average level of profitability in this industry in determining the desired debt ratio. This suggested that the management could adopt a policy of increasing the debt ratio although, in the current year, there was an increase in the company's profitability. It was also possible that the management could reduce the debt ratio although there was a decrease in the average profitability in the current year. In terms of debt policy, it seemed that the investors did not consider the average ratio of debt held in this industry to decide on buying, holding or selling stocks. The risk aspects of debt policy were not considered as a dominant factor that must be considered as the basis for investment decision making.

\section{The Influence of Indirect Effect of Profitability (Through Dividend Policy) on Stock Prices}

It was found that the dividend policy proxied by the dividend payout ratio did not mediate the influence of return on equity on the stock prices. The result implied that an increase in the average profitability of mining companies did not make it as the basis for the companies to increase their dividend ratios. Therefore, it seemed that the companies might adopt the policies to increase or decrease their dividend ratios although their average profitability conditions did not support the decision. However, according to the signaling theory, the profits obtained by the company were a positive signal for the shareholders to obtain the expected dividends (Hang et al., 2018).

This suggested that the increase in average profitability should be a sign for companies to increase their dividend ratios. It was also possible that the companies would reduce their dividend ratios, considering the decline in the average profitability of companies in the industry. In relation to the dividend policy, there seemed to be a tendency where the investors did not consider the average dividend ratio to decide whether to buy, hold or sell the company's stocks. However, according to the signaling theory, an increase in dividend payments was considered a good signal because it illustrated the conditions and good prospects of the company so that it could affect the stock price to increase (Al-Malkawi et al., 2010).

\section{Conclusion and Implication}

This study aims to obtain an empirical explanation of the role of debt policy and dividend policy as variables mediating the influence of profitability on stock prices. The result of the influence of profitability on stock prices was as expected, where increasing profitability would result in an increase in the stock prices. However, it was in contrast to the result of the influence of profitability on stock prices. The result explained that increasing profitability did not necessarily reduce debt policy.

Similarly, the result of the influence of profitability on dividend policy was also not as predicted. The result indicated that increasing profitability did not significantly increase the dividend policy. However, the test result on the influence of dividend policy on stock prices was similar to what was predicted. It shows that an increasing dividend policy would also increase stock prices. This result supports the signaling theory.

Further, the result of the debt policy and dividend policy as mediating variables did not match the researchers' expectations. The result proved that the debt policy proxied by the debt to equity ratio did not mediate the influence of return on equity on the stock prices. Similarly, the dividend policy proxied by a dividend payout ratio did not mediate the influence of return on equity on the stock prices.

Practically, these results imply that investors must consider the firm profitability and the potential dividend in their stock investment decision, however, investors don't bother to consider the debt policy in the mining sector because the debt policy doesn't have any effect on the stock price. Investors can use the dividend payout ratio as a direct signal toward the potential upside of the stock price. Hence, they could buy stock with a high dividend payout ratio to gain more stock appreciation.

The limitations of this study can be described as follows: the variation of stock price in this study is very high because this study did not separate the stock based on the trading board, so the future study can separate the analysis by the trading board (mainboard and development board); this study only using some fundamental variables, while other external/macroeconomics variable could affect the stock price and become control variables, so the future study must employ those variables also; the future study can expand the period of the study in order to find the effect's difference between i.e. pre-Global Financial Crisis in 2008 and post-Global Financial Crisis. 


\section{References}

Acheampong, P., Agalega, E., \& Shibu, A. K. (2014). The effect of financial leverage and market size on stock returns on the Ghana Stock Exchange: Evidence from selected stocks in the manufacturing sector. International Journal of Financial Research, 5(1), 125-134.

Adaoglu, C. (2000). Instability in the Dividend Policy of the Istanbul Stock Exchange (ISE) Corporations: Evidence from an Emerging Market. Emerging Markets Review, 1, 252-270.

Al-Malkawi, H. A. N., Rafferty, M., \& Pillai, R. (2010). Dividend policy: A review of theories and empirical evidence. International Bulletin of $\mathrm{Bu}$ siness Administration, 9(1), 171-200.

Arfaoui, M., \& Ben Rejeb, A. (2017). Oil, gold, US dollar and stock market interdependencies: A global analytical insight. European Journal of Management and Business Economics, 26(3), 278-293. doi: 10.1108/ ejmbe-10-2017-016

Bahreini, V., Baghbani, M., \& Bahreini, R. (2012). Analysis between financial leverage with the stock price and the operational performance of the accepted companies in Tehran's stock market. European Online Journal of Natural and Social Sciences, 2(3), 25-34.

Baron, R. M., \& Kenny, D. A. (1986). The moderatormediator variable distinction in social psychological research: Conceptual, strategic, and statistical considerations. Journal of Personality and Social Psychology, 51(6), 1173-1182. doi: https://doi.org/10.1037//0022-3514.51.6.1173

Bessler, W., \& Nohel, T. (2000). Asymmetric Information, Dividend Reductions, and Contagion Effects in Bank Stock Returns. Journal of Banking \& Finance, 24, 1831-1848.

Chabachib, M., Windriya, A., Robiyanto, R., \& Hersugondo, H. (2019). A comparative study of Indonesian and Malaysian Islamic banks. Banks and Bank Systems, 14(4), 55-68. doi:10.21511/bbs. 14(4).2019.06

Desmintari, \& Yetty, F. (2016). Effect of profitability, liquidity and assets structure on the company debt policy. International Journal of Business and Commerce, 5(6), 117-131.

Ernayani, R., Oktiviana, S., \& Robiyanto, R. (2017). The effect of return on investment, cash ratio, and debt to total assets towards dividend payout ratio (A study towards manufacturing companies listed in Indonesia Stock Exchange). Advanced Science Letters, 23(8), 7169-7199. doi:https:// doi.org/10.1166/as1.2017.9328
Eviani, A. D. (2015). Pengaruh struktur aktiva, pertumbuhan penjualan, dividen payout ratio, likuiditas dan profitabilitas terhadap struktur modal. Jurnal Akuntansi dan Sistem Teknologi Informasi, 11(2), 194-202.

Ghozali, I. (2011). Aplikasi analisis multivariate dengan menggunakan program ibm spss 19. Semarang: Badan Penerbit Undip.

Gill, A., Biger, N., \& Tibrewala, R. (2010). Determinants of dividend payout ratios: Evidence from United States. The Open Business Journal, 3, 814.

Handriani, E., \& Robiyanto, R. (2018a). Corporate finance and firm value in the Indonesian manufacturing companies. International Research Journal of Business Studies, 11(2), 113-127. doi: https://doi.org/10. 21632/irjbs.11.2.113-127

------- (2018b). Investment opportunity and industrial growth in Indonesia. International Journal of Business and Society, 19(2), 295-312.

Hang, M., Geyer-Klingeberg, J., Rathgeber, A. W., \& Stöckl, S. (2018). Measurement matters-A metastudy of the determinants of corporate capital structure. The Quarterly Review of Economics and Finance, 68, 211-225. doi:10.1016/j.qref. 2017.11.011

Haron, R., Ibrahim, K., Nor, F. M., \& Ibrahim, I. (2013). Dynamic adjustment towards target capital structure: Thailand evidence. Jurnal Pengurusan, 39, 73-82.

Hermuningsih. (2013). Pengaruh profitabilitas, growth opportunity, struktur modal terhadap nilai perusahaan pada perusahaan publik di Indonesia. Buletin Ekonomi Moneter dan Perbankan, 16 (2), 127-148. doi: https://doi.org/10.21098/bem p.v16i2.27

Hersugondo, S., Robiyanto, R., Wahyudi, S., \& Muharam, H. (2015). The world oil price movements and stock returns in several Southeast Asia's capital markets. International Journal of Applied Business and Economic Research, 13(2), 527534.

Hunjra, A. I., Shahzad, M., Chani, M. I., Hassan, S. U., \& Mustafa, U. (2014). Impact of dividend policy, earning per share, return on equity, profit after tax on stock prices. International Journal of Economics and Empirical Research, 2(3), 109115.

Indrawati, S., \& Suprihhadi, H. (2016). Pengaruh profitabilitas terhadap harga saham emiten LQ45 yang terdaftar di BEI. Jurnal Ilmu dan Riset Manajemen, 5(2). 
Khan, R., \& Meer, J. K. (2017). Determinants of dividend payout ratio: A study of KSE manufacturing firms in Pakistan. IBT Journal Of Business Studies, 13(1), 12-24.

Lewellen, W., Loderer, C., \& Martin, K. (1987). Executive compensation and executive incentive problems: An empirical analysis. Journal of Accounting and Economics, 9(3), 287-310. doi: https://doi.org/10.1016/0165-4101(87)90009-7

Margaretha, F., \& Rizki, R. A. (2010). Faktor-faktor yang mempengaruhi struktur modal pada industri manufaktur di Bursa Efek Indonesia Jurnal Bisnis dan Akuntansi, 12(2), 119-130. doi:https ://doi.org/10.34208/jba.v12i2.191.

Martins, M. M., \& Lopes, I. T. (2016). Intellectual capital and profitability: A firm value approach in the European companies. Verslas:Tteorija ir praktika, 17(3), 234-242. doi:10.3846/btp.2016 673 .

Miller, M. H., \& Modigliani, F. (1961). Dividend policy, growth, and the valuation of shares. Journal of Business, 34, 411-433.

Murhadi, W. R. (2011). Determinan struktur modal: Studi di Asia Tenggara. Jurnal Manajemen dan Kewirausahaan, 13(2), 91-98. doi:https://doi. org/10.9744/jmk.13.2.91-98.

Murniati, S. (2016). Effect of capital structure, company size, and profitability on the stock price of food and beverage companies listed on the Indonesia Stock Exchange. Information Management and Business Review, 8(1), 23-29. doi: https://doi.org/10.1016/S0304-405X(00)00078-7.

Murtiningtyas, A. I. (2012). Kebijakan deviden, kepemilikan manajerial, kepemilikan institusional, profitabilitas, resiko bisnis terhadap kebijakan hutang. Accounting Analysis Journal, 1(2), 1-6. doi: https://doi.org/10.15294/aaj.v1i2.597.

Muryanti, Y., \& Subowo, S. (2017). The effect of intelectual capital performance, profitability, leverage, managerial ownership, institutional ownership, and independent commissioner on the disclosure of intelectual capital. Accounting Analysis Journal, 6(1), 56-62. doi:https://doi.org/10. 15294/aaj.v6i1.11259.

Nnadi, M. (2016). Accounting factors affecting the capital structure in the Asian Economic
Community International Journal of Accounting Research, 5(1), 1-9. doi:https://doi.org/10.4172/ 2 472-114X.1000139.

Nurlita, E., \& Robiyanto, R. (2018). The effect of financial performance and company size on the Indonesian sharia stocks. Jurnal Akuntansi Keuangan dan Bisnis, 11(2), 87-96.

Onofrei, M., Tudose, M. B., Durdureanu, C., \& Anton, S. G. (2015). Determinant factors of firm leverage: An empirical analysis at Iasi county level. Procedia Economics and Finance, 20, 460-466. doi: https://doi.org/10.1016/s2212-5671(15) 00097-0.

Putra, A. R., \& Robiyanto, R. (2019). The effect of commodity price changes and USD/IDR exchange rate on Indonesian mining companies' stock return. Jurnal Keuangan dan Perbankan, 23, 103 -115). doi:https://doi.org/10.26905/jkdp. v23i1. 2084.

Robiyanto, R. (2018). The dynamic correlation between ASEAN-5 stock markets and world oil prices. Jurnal Keuangan dan Perbankan, 22(2), 198-210. doi:https://doi.org/10.26905/jkdp.v22i2. 1688.

Sahabuddin, Z. A. (2017). Asset structure impact on capital structure of capital market-listed firms in Indonesia and Malaysia. Jurnal Keuangan dan Perbankan, 21(3), 376-386. doi:https://doi.org/ 10.26905/jkdp.v21i3.1312.

Subiyantoro, E., \& Andreani, F. (2013). Analisis faktor-faktor yang mempengaruhi harga saham (Kasus perusahaan jasa perhotelan yang terdaftar di pasar modal Indonesia). Jurnal Manajemen dan Kewirausahaan, 5(2), 171-180. doi:https:// doi.org/10.9744/jmk.5.2.pp.\%20171-180.

Wijaya, R. (2017). kinerja keuangan dan ukuran perusahaan terhadap harga saham dengan kebijakan dividen sebagai variabel intervening. Jurnal Keuangan dan Perbankan, 21(3), 1-14. doi: https://doi.org/10.26905/jkdp.v21i3.1432.

Zakaria, Z., Muhammad, J., \& Zulkifli, A. H. (2012). The impact of dividend policy on the share price volatility: Malaysian construction and material companies. International Journal of Economics and Management Sciences, 2(5), 1-8. 